\title{
Evaluation of Water Productivity in Integrated Farming System in Wetland Situation of Western Zone of Tamil Nadu
}

\author{
J. Bhuvaneswari ${ }^{1}$, G. Thiyagarajan ${ }^{2 *}$, M. Manikandan ${ }^{3}$, \\ S. K. Natarajan ${ }^{4}$ and S. Thenmozhi ${ }^{5}$ \\ ${ }^{1}$ Agricultural College and Research Institute, Tamil Nadu Agricultural University, \\ Killikulam, India \\ ${ }^{2}$ Water Technology Centre, ${ }^{4}$ Department of Agronomy, Tamil Nadu Agricultural University, \\ Coimbatore, India \\ ${ }^{3}$ Agricultural Engineering College and Research Institute, Tamil Nadu Agricultural \\ University, Kumulur, India \\ ${ }^{5}$ Krishi Vigyan Kendra, Tamil Nadu Agricultural University, Pongalur, India \\ *Corresponding author
}

\section{A B S T R A C T}

\begin{tabular}{|l|}
\hline K e y w o r d s \\
$\begin{array}{l}\text { Integrated Farming } \\
\text { System, Wetland, } \\
\text { Water productivity, } \\
\text { Yield, Economics }\end{array}$ \\
\hline Article Info \\
$\begin{array}{l}\text { Accepted: } \\
17 \text { October } 2020 \\
\text { Available Online: } \\
10 \text { November } 2020\end{array}$ \\
\hline
\end{tabular}

Integrated Farming System (IFS) for wetland situation experiments were conducted in Southern block of Agricultural Research Station, Bhavanisagar during 2013 to 2017 under All India Co-ordinated Project on Irrigation Water Management. The objective of the experiment was to work out the water requirements for cropping and livestock components in IFS under wetland situation. In Conventional farming system (CFS), Rice - Rice - Pulse cropping system was followed in one-hectare area. In wetland IFS, Rice - Rice - Pulses $\left(8000 \mathrm{~m}^{2}\right)$, Cumbu Napier grass $\left(1500 \mathrm{~m}^{2}\right)$, Fish pond $\left(300 \mathrm{~m}^{2}\right)$ and others $\left(200 \mathrm{~m}^{2}\right)$ [Dairy unit ( 2 cows), Poultry unit (30 desi birds), Pigeon unit (10 pairs), Duck (30 birds)].In IFS, rice crop was cultivated in System of Rice Intensification (SRI) method. Rice (IW Ponni), Pulse (Greengram - CO6) and Cumbu Napier grass $(\mathrm{CO}(\mathrm{CN}) 4)$ were used for experiment. The wetland IFS recorded lower water consumed $\left(20454 \mathrm{~m}^{3}\right)$ compared to CFS $(29620$ $\mathrm{m}^{3}$ ). The higher gross income of Rs.527825/-, physical water productivity $\left(3.68 \mathrm{kgm}^{-3}\right)$ and economic water productivity $\left(25.80 \mathrm{Rs}_{\mathrm{m}} \mathrm{m}^{-3}\right)$ recorded under IFS compared to CFS. It was concluded that the IFS not only influenced the yield but also higher irrigation water productivity. Moreover, benefit-cost ratios with different discount rates indicated that IFS in wetland situation is economically significant.

\section{Introduction}

Small and marginal farmers are the core of the Indian rural economy constituting $85 \%$ of the total farming community but possessing only $44 \%$ of the total operational land (GoI
2014). The average size of operational land holdings has reduced by half from 2.28 ha in 1990-91 to 1.16 ha in 2015-16. The operational farm holding in India is still declining. The declining trend of per capita land availability posses a serious challenge to 
the sustainability and profitability of farming (Siddeswaran et al., 2012). Due to ever increasing population and shrinking land resources in the country, practically there is hardly any scope for horizontal expansion of land for food production. Only vertical expansion is possible by integrating appropriate farming components that require lesser space and time to ensure reasonable periodic income to farm families (Gill et al., 2009). The rationale behind integrated farming is to minimize wastes from the various subsystems on the farm. Wastes or by-products from each subsystem are used as inputs to other subsystems to improve the productivity and lower the cost of production of the outputs of the various subsystems (Edwards et al., 1988, Gill et al., 2009). IFS seem to be the possible solution with the changing agrarian scenario of India.

Overall an integrated farming system fulfil the multiple objectives of making farmers self-sufficient by ensuring the family members a balance diet, improving the standard of living through maximizing the total net returns and provide more employment, minimizing the risk and uncertainties and keeping harmony with environment (Mali et al., 2014). Simultaneous production of fish in ponds, with pigs, duck or chicken rearing in pens, beside or over the ponds constitutes a continuous organic fertilization of the pond by the livestock. This practice increases the efficiency and rentability of both livestock farming and fish culture through the profitable utilization of animal and feed wastes (Vincke, 1988; Gill et al., 2005).

The field experiments were conducted at Agricultural Research Station, Bhavanisagar under AICRP- Irrigation Water Management project resulted evaluation of Integrated farming system compared to conventional method of farming in wetland situation.

\section{Materials and Methods}

The IFS for wetland situation experiments were conducted in Southern block of Agricultural Research Station, Bhavanisagar during 2013 to 2017 under All India Coordinated Project on Irrigation Water Management. The objective of the experiment were to work out the water requirements for cropping components and livestock components in Integrated Farming System under wetland situation, to assess the multiple use of water by way of estimating water use and water productivity in different components of farming system under wetland situations in western zone of Tamil Nadu. For conventional method Rice - Rice - Pulse were followed in one hectare area. In wetland Integrated Farming Systems, the experiment consisted of one hectare area including the components such as Rice - Rice - Pulses $\left(8000 \mathrm{~m}^{2}\right)$, Cumbu napier grass $\left(1500 \mathrm{~m}^{2}\right)$, Fish pond $\left(300 \mathrm{~m}^{2}\right)$ and others $\left(200 \mathrm{~m}^{2}\right)$ [Dairy unit (2 cows), Poultry unit (30 desi birds), Pigeon unit (10 pairs), Duck (30 birds)]. Since it is a farming system experiment it does not involve any specific design and non replicated.Vaccination was done for the poultry birds regularly for Ranikhet disease. Vaccine for Foot and Mouth disease were given for the milch cows once in 6 months.

In integrated farming system, for rice crop, System of Rice Intensification (SRI) method adopted. In which irrigation to a maximum depth of $2.5 \mathrm{~cm}$ after development of hairline cracks in the soil. For pulse crop irrigation given based on IW/CPE ratio. For Cumbu Napier grass, surface irrigation given once in ten days. In conventional method of rice $\mathrm{cm}$ depth of irrigation adopted. The major soil type of the study area was sandy loam in nature and the soil fertility status was medium in available nitrogen, phosphorus and potash. Two methods of cultivation viz., Integrated 
farming system and conventional method were compared by using the varieties for rice (IW Ponni), Pulse (Greengram - CO6) and Cumbu Napier grass $(\mathrm{CO}(\mathrm{CN}) 4)$. The total water use was calculated by adding irrigation water applied and effective rainfall. Yield was recorded and total water used, water use efficiency (WUE) and economics were worked out and presented.

\section{Results and Discussion}

In integrated crop livestock farming system, crop residues can be used for animal feed, while manure from livestock can enhance agricultural productivity by intensifying nutrients that improve soil fertility as well as reducing the use of chemical fertilizers (Gupta et al., 2012). Integration of crop sequences with animal component improved the system profitability in totality even on small farm of 0.50 ha having $32 \%$ slope (converted into terraces) at Umiam, Meghalaya, which contributed more than 55\% of the total farm income and made the system more remunerative (Panwar, 2014). The inclusion of animal component in the system set a positive link on sustainability by generating cash income, improving family nutrition and recycling crop residues and livestock refuse into valuable nutrient source for crops (Saxena et al., 2003). Integration of livestock with crops on watershed and individual holding basis has been reported to improve the traditional farming system on sustainable and eco-friendly basis (Dhiman et al., 2003) (Table 1).

Table.1 Comparison of water productivity and Economics of Wetland IFS and CFS (Average data)

\begin{tabular}{|c|c|c|c|c|c|c|}
\hline Enterprises & $\begin{array}{c}\text { Area } \\
\text { (ha) }\end{array}$ & $\begin{array}{c}\text { Water } \\
\text { usage }\left(\mathrm{m}^{3}\right)\end{array}$ & $\begin{array}{c}\text { Unit } \\
\text { Yield (kg) }\end{array}$ & $\begin{array}{c}\text { Gross } \\
\text { Income (Rs.) }\end{array}$ & $\begin{array}{c}\text { Physical } \\
\text { WP(kg m³ })\end{array}$ & $\begin{array}{c}\text { Economic } \\
\text { WP }\left(\text { Rs.m }^{-3}\right)\end{array}$ \\
\hline \multicolumn{7}{|c|}{ Integrated Farming System (IFS) } \\
\hline Rice & \multirow[t]{3}{*}{0.8} & 7008 & 5540 & 71560 & 0.79 & 10.23 \\
\hline Rice & & 7176 & 5060 & 75900 & 0.71 & 10.58 \\
\hline Pulse & & 3192 & 685 & 54800 & 0.22 & 17.27 \\
\hline CO4(CN) grass & 0.15 & 2610 & 46179 & 69268 & 17.69 & 26.53 \\
\hline Dairy & 2 Nos & $99.34 *$ & 5006 lit & 175210 & 50.40 & 1764.13 \\
\hline Fish pond & 0.03 & $360 * *$ & 319 & 31850 & 0.88 & 88.47 \\
\hline Poultry & 30 Nos & 0.91 & 84 & 16700 & 92.07 & 18413.07 \\
\hline Pigeon unit & 20 Nos & 0.37 & 15 & 3000 & 40.89 & 4256.48 \\
\hline Duck & 30 Nos & 6.95 & 348 & 29538 & 50.08 & 8177.36 \\
\hline Total (1 ha) & & 20454 & 63234 & 527825 & 3.09 & 25.80 \\
\hline \multicolumn{7}{|c|}{ Conventional Farming System (CFS) - Rice - Rice - Pulse (1 ha) } \\
\hline Rice & 1 & 11795 & 5317 & 77123 & 0.45 & 6.56 \\
\hline Rice & 1 & 12835 & 5439 & 81585 & 0,43 & 6.41 \\
\hline Pulse & 1 & 4990 & 778 & 62200 & 0.16 & 12.56 \\
\hline Total (1 ha) & & 29620 & 11533 & 220908 & 1.04 & 7.47 \\
\hline
\end{tabular}

In wetland situation, each one hectare area was allocated for Conventional Farming System (CFS) and Integrated Farming System
(IFS). The total water consumed in one hectare IFS was lower $\left(20454 \mathrm{~m}^{3}\right)$ compared to conventional farming system $\left(29620 \mathrm{~m}^{3}\right)$. 
The higher gross income of Rs. 527825 recorded under IFS compared to CFS (Rs.220908). In wetland, the higher physical water productivity $\left(3.09 \mathrm{kgm}^{-3}\right)$ and economic water productivity $\left(25.80\right.$ Rs. $\left.\mathrm{m}^{-3}\right)$ were recorded. This might be due to efficient utilisation of resources (land and water).

Balusamy et al., (2003) explained that the gross income obtained in rice + Azolla + fish was $25.7 \%$ more over the rice crop and $6.9 \%$ more over the rice + fish. The net income followed the same trend. Thus rice + Azolla + fish on an average gave $8817 /$ ha more over the rice monoculture and 3219/ha over the rice + fish. This model was proposed for extensive scale adoption in Tamil Nadu. A net profit of about $200 \%$ of the total cost indicates the economic viability of the technology. It has considerable potential to provide food security, nutritional benefits, employment generation and providing additional income to resource poor small farmers.

With rice-based IFS in Kerala, major returns by $79 \%$ from coconut-banana intercropping in the dykes and field bunds (Mathew and Varughese 2007). Duck droppings also resulted in enhanced profit percentage by 20.5 with net income of 27800/ha. The above amendments have also enhanced the physical properties of soil like bulk density, porosity, aggregates, infiltration rate etc. Channabasavanna et al., (2002) observed from integrated farming system studies at Sirupura that rice-fish-poultry combinations gave highest net income (> 157000/ha) with an improvement in soil health. Kumar et al., (2012) studied different IFS models at Patna and identified crop + fish + duck + goat as the best integrated farming system in terms of productivity and employment generation (752 man-days/year) due to better involvement of farm family labours throughout the year.
In conclusion the results of water productivity in integrated farming system in western zone of Tamil Nadu revealed that the wetland IFS recorded lower water consumed $\left(20454 \mathrm{~m}^{3}\right)$ compared to conventional farming system $\left(29620 \mathrm{~m}^{3}\right)$. The higher gross income of Rs.527825/-, physical water productivity $\left(3.68 \mathrm{kgm}^{-3}\right)$ and economic water productivity (25.80 Rs. $\mathrm{m}^{-3}$ ) recorded under IFS compared to CFS. It is concluded from the study that Integrated Farming system favourably influenced the yield which resulted in higher irrigation water productivity against lower amounts of water applied. Moreover, benefitcost ratios with different discount rates indicated that Integrated Farming system in wetland situation is economically significant.

\section{References}

Balusamy M, Shanmugham P M and Baskaran R. 2003. Mixed farming an ideal farming. Intensive Agriculture 41 (11-12): 20-5.

Channabasavanna A S, Itnal C J and Patil S G. 2002. Productivity, economics analysis and changes in physicochemical properties as influenced by integrated rice-based farming system. Indian Journal of Agronomy 46(1): 15.

Dhiman K R, Bujarbaruah K M and Satapathy K K. 2003. Integrated farming system for sustainable development of rainfed agriculture in North Eastern region.

(In) Proceedings of International Conference on World Perspective on Short Rotation Forestry for Industrial and Rural Development, held during 713 September 2003 at Solan, Himachal Pradesh, p 154.

Edwards P, Pullin R S V and Gartner J A. 1988. Research and education for the development of integrated croplivestock-fish farming systems in the tropics. ICLARM Studies and Reviews 
16, Manilla, Philippines. and employment generation options for small and marginal farmers. PDCSR, Modipuram, pp 109-18.

Gill M S, Singh J P and Gangwar K S. 2009. Integrated farming System and agriculture sustainability. Indian Journal of Agronomy 54(2): 128-39.

GoI. 2014. Agricultural statistics at a glance, Directorate of Economics and Statistics, Govt. of India, New Delhi.

Gupta V, Rai P K and Risam K S. 2012. Integrated crop-livestock farming systems: A strategy for resource conservation and environmental sustainability. Indian Research Journal of Extension Education, 2: 49-54.

Mali Hansram, Kumar Amit and Katara Pawan. 2014. Integrated farming system for irrigated and rainfed conditions. (In) Proceedings of National Symposium on Agricultural Diversification for Sustainable Livelihood and Environmental Security, held during 18-20 November 2014 at Ludhiana, Punjab, p 546.

Mathew T and Varughese K. 2007. Nutrient flow and economics of integrated farming system practiced in the coastal region
Panwar A S. 2014. Livestock based farming system for small and marginal farmers of north-eastern hill region. (In) Proceedings of National Symposium on Agricultural Diversification for Sustainable Livelihood and Environmental Security, pp 531-32, held during 18-20 November at Ludhiana, Punjab.

Saxena D C, Singh N P, Satapathy K K, Panwar A S and Singh J L. 2003. Sustainable farming systems for hill agriculture. (In) Proceeding of National Seminar 'Approaches for Increasing Agricultural Productivity in Hill and Mountain Ecosystem', held during 18-20 October, 2001at Barapani, pp 73-85.

Siddeswaran K, Sangetha S P and Shanmugam P M. 2012. Integrated farming system for the small irrigated upland farmers of Tamil Nadu. Extended Summaries Vol 3: $3 r d$ International Agronomy Congress, held during 26-30 November 2012 at New Delhi, pp 992-3.

Vincke M. 1988. La rizipisciculture et les elevageassociesen Afrique. CIFA Technical Paper (4) Suppl 1: 659-707.

\section{How to cite this article:}

Bhuvaneswari, J., G. Thiyagarajan, M. Manikandan, S. K. Natarajan and Thenmozhi, S. 2020. Evaluation of Water Productivity in Integrated Farming System in Wetland Situation of Western Zone of Tamil Nadu. Int.J.Curr.Microbiol.App.Sci. 9(11): 2392-2396. doi: https://doi.org/10.20546/ijcmas.2020.911.287 